American Journal of Applied Sciences 9 (8): 1300-1306, 2012

ISSN 1546-9239

(C) 2012 Science Publications

\title{
Fatty Acid Content of Bovine Milkfat From Raw Milk to Yoghurt
}

\author{
${ }^{1}$ O.O. Santos Júnior, ${ }^{2}$ M.R. Pedrão, \\ ${ }^{2}$ L.F. Dias, ${ }^{2}$ L.N. Paula, ${ }^{2}$ F.A.G. Coró and ${ }^{2}$ Nilson Evelazio De Souza \\ ${ }^{1}$ Department of Chemistry, \\ State University of Maringa, 87020-900, Maringa, Parana State, Brazil \\ ${ }^{2}$ Department of Food Technology, Federal Technologic University of Parana, \\ 86036-370, Londrina, Parana State, Brazil
}

\begin{abstract}
Problem statement: The present study aimed to study the evolution of fatty acid content, focusing on rumenic acid content, from raw milk to yoghurt processed from this milk. Approach: Milk samples were collected in a dairy plant in the northwest of Paraná State weekly in January 2011 (Brazilian summer). It processed one truck load of 26,000 L of refrigerated type-C (whole standardized milk with a minimum of $3 \%$ fat) milk per day, mostly from the city of Lobato, Paraná, produced mainly by Gir (Bos indicus) cattle raised on stargrass (Cynodon nlenfuensis var. nlenfuensis) pasture. Results: Saturated Fatty Acid (SFA) were the most abundant, particularly palmitic (16:0), stearic (18:0) and myristic (14:0). Among the Monounsaturated Fatty Acid (MUFA), Polyunsaturated Fatty Acid (PUFA) and trans fatty acid, oleic acid (18:1n-9), linoleic acid (18:2n-6), elaidic acid (t9-18:1) and c9, t11-18:2 (rumenic acid) predominated. It was detected significant differences $(\mathrm{p}<0.05)$ in the quantification of isomer $\mathrm{c} 9, \mathrm{t} 11-18: 2$ of Conjugated Linoleic Acid (CLA). Raw milk had the largest content of rumenic acid $\left(14.91 \pm 0.17 \mathrm{mg} \mathrm{g}^{-1}\right.$ of lipids), decreasing to $6.22 \pm 0.20$ after pasteurization and to $5.41 \pm 0.18 \mathrm{mgg}^{-1}$ in yoghurt. Conclusion/Recommendations: It is demonstrated that pasteurization and yoghurt making affect the CLA contents.
\end{abstract}

Key words: Saturated Fatty Acid (SFA), Conjugated Linoleic Acid (CLA), Monounsaturated Fatty Acid (MUFA), High Temperature Short Time (HTST)

\section{INTRODUCTION}

The term Conjugated Linoleic Acid (CLA) refers to a mixture of linoleic acid isomers $(c 9, c 12-18: 2 ; t 10$, $c 12-18: 2 ; c 9, t 11-18: 2$ (rumenic acid), $t 10, t 12-18: 2 ; t 9$, $t 11-18: 2 ; t 8, t 10-18: 2 ; t 7, t 9-18: 2 ; t 8, c 10-18: 2)$. This group of compounds is object of a large number of studies and represents a new and wide field of study on fatty acid and their relationship with human health (Autores, 2009). Among the potential benefits that have been reported are effects on the body composition, cardiovascular diseases and the immunologic system (Ip et al., 2002; Ledoux et al., 2007; Cook et al., 1993).

Two CLA isomers have gained importance in food research worldwide. Isomer $t 10, c 12-18: 2$ a powerful inhibitor of the synthesis of fat in milk and responsible for the redistribution of fat in muscle, contributing to reduce the fat mass and increase the lean mass (Mourão et al., 2005; Dugan et al., 1997; Chardigny et al., 2003; Gaullier et al., 2005; Degrace et al., 2003). Isomer $c 9, \quad t 11-18: 2$ has demonstrated antitumoral properties, reducing the incidence of breast cancer (Mourão et al., 2005; Dugan et al., 1997; Chardigny et al., 2003; Gaullier et al., 2005; Degrace et al., 2003; Ou et al., 2007; Lavillonnière et al., 2003; Belury et al., 1996; Hubbard et al., 2000; Molkentin, 1999; Chardigny et al., 2008).

The pasture has major effects by decreasing saturated FA and increasing FA considered as favorable for human health (c9-18:1, 18:3n-3 and $c 9$, t11-CLA), compared to winter diets, especially those based on maize silage and concentrates (Chilliard et al., 2007).

As CLA is a product of incomplete biohydrogenation (Kepler et al., 1966; Kramer et al., 1998), foods derived from ruminants are the main sources of CLA in the human diet. Thus, after years of banning dairy products, the existence of such potentially beneficial product may be an opportunity for a new perception of animal-origin products by the consumers and the medical community.

There were some studies on the effects of process, especially the effect of starter cultures on CLA contents in yoghurt and cheeses and the effect of ripening on CLA contents of cheeses and on the process of milk to cream and then to butter (Shantha et al., 1995; Jiang et al., 1998; Sieber et al., 2004; Gnädig et al., 2004;

Corresponding Author: O.O. Santos Júnior, Department of Chemistry, State University of Maringa, 87020-900, Maringa, Parana State, Brazil Tel: +55 (43) 3315-6130 Fax: +55 (43) 33156121 
Ledoux and Laloux, 2006; Pereda et al., 2008). However, there is a lack of data on the effect of the thermal processes used in the preservation of milk and its derivatives regarding their effects on the nutritional and organoleptic properties of dairy products (Pereda et al., 2008; Raynal-Ljutovac et al., 2007; Rynne et al., 2004).

To our knowledge, there is no report on the effects of pasteurization on the fatty acid profile of milk and derivatives. The aim of the study was to determine the fatty acid, including CLA, contents of raw and pasteurized milk and yoghurt, focusing of the evolution of the rumenic acid content from raw milk to yoghurt during processing.

\section{MATERIALS AND METHODS}

Sampling: Milk samples were collected in a dairy plant in the northwest of Paraná State weekly in January 2011 (Brazilian summer). It processed one truck load of $26,000 \mathrm{~L}$ of refrigerated type-C (whole standardized milk with minimum of $3 \%$ fat) milk per day, mostly from the city of Lobato, Paraná, produced mainly by Gir (Bos indicus) cattle raised on stargrass (Cynodon nlenfuensis var. nlenfuensis) pasture. The tank outlets were then connected to stainless steel pipes and positively pumped through a closed system to a vertical isothermal storage tank with capacity of $30,000 \mathrm{~L}$ provided with a stirrer. A total of five lots of $250 \mathrm{~mL}$ raw milk were carried out weekly in January 2011 (Brazilian summer). Each lot was sampled three times in order to perform analysis in triplicates. Raw milk samples were transferred in sterilized tubes. The tubes were immediately cooled down to $20^{\circ} \mathrm{C}$ after sampling, then frozen $\left(-18^{\circ} \mathrm{C}\right)$ and transported in thermal recipients.

From the vertical isothermal tank where the raw milk was initially stored, it is pumped through a stainless steel closed system to a High Temperature, Short Time (HTST) type pasteurizer provided with a digital temperature controller. The milk is heated to $75^{\circ} \mathrm{C} / 15 \mathrm{~s}$ and immediately cooled to $5^{\circ} \mathrm{C}$ for pasteurization. Then, it follows to another vertical isothermal storage balloon with capacity of $30,000 \mathrm{~L}$ provided with a stirrer.

For each of the five week lots, three samples of 250 $\mathrm{mL}$ pasteurized milk were collected from the tank and transferred in sterilized tubes. The tubes were immediately cooled after sampling, frozen $\left(-18^{\circ} \mathrm{C}\right)$ and transported in thermal recipients.

From the vertical storage balloon the pasteurized milk runs through a stainless steel closed system to a preparation tank, where it is added with sugar and stabilizers under constant stirring according to the plant formulation. Next, the mixture is re-pasteurized $\left(85^{\circ} \mathrm{C} / 10 \mathrm{~min}\right)$ and goes to fermentation tanks, where the temperature reaches $42^{\circ} \mathrm{C}$. The lyophilized starting mix Yo Mix from Danisco is added, the tank is sealed and the milk rests until $\mathrm{pH} 4.7$ is reached, then it is cooled to $20^{\circ} \mathrm{C}$ under light agitation. To this mixture is added the wished fruit flavor and the yoghurt is cuppacked in a Brascop-type machine.

For each of the five week lots, three samples of $500 \mathrm{~mL}$ yoghurt were collected after packing and transferred in sterilized tubes. The tubes were immediately cooled after sampling, frozen $\left(-18^{\circ} \mathrm{C}\right)$ and transported in thermal recipients. The three samples of each lot for all matrixes (raw milk, pasteurized milk and yoghurt) were analyzed individually and within the same time.

Lipid extraction and analysis of fatty acid: Total lipids were determined by the Folch et al. (1957) method using chloroform, methanol and water (2:1:1).

The lipids were converted into fatty acid methyl esters following Bannon et al. (1982) to a screw cap tube with approximately $150 \mathrm{mg}$ of lipids was added $0.25 \mathrm{~mol} \mathrm{~L}^{-1} 5.0 \mathrm{~mL}$ of sodium methoxide solution in methanol/ethylic ether (1:1). The tube was vigorously agitated for approximately $3 \mathrm{~min}$. Next, $3.0 \mathrm{~mL}$ of isooctane and $15 \mathrm{~mL}$ of saturated sodium chloride were added. The tube was vigorously agitated again and rested for phase separation. The supernatant was collected in labeled Eppendorf tubes for chromatographic analysis.

The method originally involves fast heating under reflux after the addition of the transesterifying agent; however, this was not done to avoid isomerization of conjugated dienes of linoleic acid, as proposed by Simionato et al., 2010).

Chromatographic analysis was performed in a gas chromatograph Varian, model CP 3380, equipped with a flame ionization detector, split/splitless-type injector, fused silica capillary column CP Select CB-Fame ( $100 \%$ bonded cyanopropyl, $100 \mathrm{~m}, 0.25 \mathrm{~mm}$ i.d., 0.39 $\mu \mathrm{m}$ stationary phase). The best resolution operation parameters were: injector and detector temperature $235^{\circ} \mathrm{C}$; column temperature $65^{\circ} \mathrm{C}$ for $4 \mathrm{~min}$, followed by a $16^{\circ} \mathrm{C} / \mathrm{min}$ ramp up to $185^{\circ} \mathrm{C}$, for $12 \mathrm{~min}$. A second ramp of $20^{\circ} \mathrm{C} / \mathrm{min}$ up to $235^{\circ} \mathrm{C}$ for $14 \mathrm{~min}$ was programmed. The total analysis time was $40 \mathrm{~min}$.

The following gas flows were used: Carrier gas $\left(\mathrm{H}_{2}\right)$ $1.4 \mathrm{~mL} \cdot \mathrm{min}^{-1}$, auxiliary $\left(\mathrm{N}_{2}\right) 30 \mathrm{~mL} \cdot \mathrm{min}^{-1}$ and $\mathrm{H}_{2}$ and flame synthetic air, 30 and $300 \mathrm{~mL} \cdot \mathrm{min}^{-1}$, respectively. The sample split rate used was $1 / 80$. Injections were performed in duplicate in volumes of $2 \mu \mathrm{L}$. The peak 
areas of fatty acid methyl esters were determined with the software workstation version 5.0 (Varian).

Identification of fatty acid: The fatty acid methyl esters were identified by comparison of retention times of the sample constituents with a mixture of 37 fatty acid methyl ester standards (189-19 Sigma, USA) and comparison with retention times of methyl ester standards containing the geometric isomers $c 9, t 11-18: 2$ and $t 10, c 12-18: 2$ of linoleic acid (O-5626, Sigma, USA).

Fatty acids were quantified as $\mathrm{mg} \mathrm{g}^{-1}$ of total lipids compared to the internal standard, methyl tricosanoate (23:0) from Sigma. Before weighing the sample, 1.00 $\mathrm{mL}$ of internal standard solution $\left(1 \mathrm{mg} \mathrm{mL}^{-1}\right)$ was added to the esterification recipient, after which the solvent was evaporated under $\mathrm{N}_{2}$ flow.

The fatty acid methyl esters were quantified after verification of agreement between the theoretical and experimental response factor. The fatty acid concentration was calculated according to Joseph and Ackman (1982) using the equation:

$$
\mathrm{C}(\mathrm{mgg}-1)=\frac{\mathrm{A}_{\mathrm{X}} \cdot \mathrm{M}_{23: 0} \cdot \mathrm{T}_{\mathrm{RF}}}{\mathrm{A}_{23: 0} \cdot \mathrm{M}_{\mathrm{A}} \cdot \mathrm{F}_{\mathrm{CT}}}
$$

Where:

$\begin{array}{ll}\mathrm{A}_{\mathrm{X}} & =\text { Area of fatty acid methyl esters } \\ \mathrm{A}_{23: 0} & =\text { Area of the internal standard } \\ \mathrm{M}_{23: 0}= & \text { Mass of internal standard added to the } \\ & \text { sample }(\mathrm{mg}) \\ \mathrm{MA} & =\text { Sample mass }(\mathrm{g}) \\ \mathrm{TRF} & =\end{array}$

Statistical analysis: The results were submitted to Variance Analysis (ANOVA) at 5\% significance level using the software StatSoft (2005). The mean values were compared with Tukey's test.

\section{RESULTS}

The total lipids of the samples were determined and are given in Table 1 . They varied from $2.41 \%$ in yoghurt to $3.66 \%$ in raw milk.

Figure 1 shows the 26 Fatty Acid (FA) identified in the samples and the internal standard used. The analyzed samples presented 26 fatty acid, which were identified and quantified (Table 2).

Figure 2 shows that women would need to take 2.5 glasses of raw milk or 6 glasses of pasteurized milk or 9 cups of yoghurt a day and men, 3 glasses of raw milk or 8 glasses of pasteurized milk or 11 cups of yoghurt to ingest the required amount of CLA recommended by Sieber et al. (2004).

Table 1:Total lipid content of raw milk, pasteurized 1 milk and yoghurt

\begin{tabular}{ll}
\hline Sample & Total lipids (\%) \\
\hline Raw milk & $3.66^{\mathrm{a}} \pm 0.08$ \\
Pasteurized milk & $3.04^{\mathrm{b}} \pm 0.03$ \\
Yoghurt & $2.41^{\mathrm{c}} \pm 0.03$ \\
\hline
\end{tabular}

* Results in percentage as mean \pm standard deviation of triplicate analysis results of five different lots $(n=15)$. Means followed by different letters in the same column are significantly different by Tukey's test at $5 \%$ probability level

Table 2: Fatty acid content (mg/g milkfat)* in raw milk, pasteurized 1 milk and yoghurt

\begin{tabular}{|c|c|c|c|}
\hline Fatty acids & Raw milk & Pasteurized milk & Yoghurt \\
\hline $4: 0$ & $31.39 \mathrm{a} \pm 0.55$ & $31.18 \mathrm{a} \pm 0.65$ & $15.05 \mathrm{~b} \pm 0.06$ \\
\hline $6: 0$ & $9.67 a \pm 0.32$ & $9.60 \mathrm{a} \pm 0.24$ & $8.81 \mathrm{a} \pm 0.12$ \\
\hline $8: 0$ & $7.46 a \pm 0.25$ & $7.53 a \pm 0.19$ & $4.34 \mathrm{~b} \pm 0.14$ \\
\hline 10:0 & $19.10 \mathrm{a} \pm 0.23$ & $17.76 \mathrm{a} \pm 0.55$ & $10.89 \mathrm{~b} \pm 0.09$ \\
\hline 11:0 & $2.51^{\mathrm{a}} \cdot \mathrm{b} \pm 0.20$ & $3.14 a \pm 0.06$ & $1.83 \mathrm{~b} \pm 0.04$ \\
\hline 12:0 & $23.04 \mathrm{a} \pm 0.22$ & $20.66 \mathrm{a} \pm 0.43$ & $13.54 \mathrm{~b} \pm 0.07$ \\
\hline 14:0 & $93.56 a \pm 1.24$ & $97.85 b \pm 0.45$ & $57.87 \mathrm{c} \pm 0.56$ \\
\hline $14: 1 n-11$ & $2.54 a \pm 0.33$ & $2.38 \mathrm{a} \pm 0.17$ & $2.33 a \pm 0.04$ \\
\hline $14: 1 n-9$ & $10.06 a \pm 0.45$ & $7.98 b \pm 0.32$ & $6.78 b \pm 0.03$ \\
\hline $14: 1 n-7$ & $4.70 \mathrm{a} \pm 0.37$ & $4.73 a \pm 0.08$ & $3.67 b \pm 0.03$ \\
\hline $15: 0$ & $5.90 \mathrm{a} \pm 0.28$ & $5.45 a \pm 0.16$ & $6.15 a \pm 0.07$ \\
\hline $15: 1 n-7$ & $2.59 \mathrm{a} \pm 0.19$ & $2.47 \mathrm{a} \pm 0.14$ & $1.26 \mathrm{~b} \pm 0.06$ \\
\hline $16: 0$ & $291.99 \mathrm{a} \pm 2.27$ & $288.58 \mathrm{a} \pm 2.02$ & $157.95 b \pm 0.83$ \\
\hline $16: 1 n-11$ & $1.74 \mathrm{a} \pm 0.04$ & $1.77 \mathrm{a} \pm 0.08$ & $1.50 \mathrm{a} \pm 0.02$ \\
\hline $16: 1 n-9$ & $1.71 \mathrm{a} \pm 0.07$ & $1.68 \mathrm{a} \pm 0.03$ & $1.27 \mathrm{a} \pm 0.03$ \\
\hline $16: 1 n-7$ & $12.33 \mathrm{a} \pm 1.18$ & $14.40 \mathrm{a} \pm 0.12$ & $2.67 \mathrm{~b} \pm 0.03$ \\
\hline 17:0 & $5.78 \mathrm{a} \pm 0.35$ & $6.10 \mathrm{a} \pm 0.04$ & $4.94 a \pm 0.12$ \\
\hline $17: 1 \mathrm{n}-7$ & $2.30 \mathrm{a} \pm 0.03$ & $2.34 \mathrm{a} \pm 0.15$ & $1.65 \mathrm{~b} \pm 0.04$ \\
\hline $18: 0$ & $101.97 \mathrm{a} \pm 0.94$ & $104.33 \mathrm{a} \pm 0.97$ & $71.93 b \pm 0.38$ \\
\hline $18: 1 n-11 t$ & $32.54 \mathrm{a} \pm 0.49$ & $27.55 \mathrm{a} \pm 0.51$ & $18.01 \mathrm{~b} \pm 0.38$ \\
\hline $18: 1 n-9$ & $208.40 \mathrm{a} \pm 1.09$ & $217.45 a \pm 1.96$ & $125.97 b \pm 0.81$ \\
\hline $18: 1 n-7$ & $2.82 \mathrm{a} \pm 0.15$ & $2.65 a \pm 0.18$ & $2.72 b \pm 0.03$ \\
\hline $18: 2 n-6 t$ & $2.28 \mathrm{a} \pm 0.15$ & $2.21 \mathrm{a} \pm 0.04$ & $2.22 a \pm 0.05$ \\
\hline $18: 2 n-6$ & $15.03 a \pm 0.22$ & $13.88 \mathrm{a} \pm 0.39$ & $10.70 \mathrm{~b} \pm 0.25$ \\
\hline $18: 3 n-3$ & $4.71 \mathrm{a} \pm 0.13$ & $4.05 a \pm 0.06$ & $2.16 b \pm 0.03$ \\
\hline $18: 2 \mathrm{c} 9 \mathrm{t} 11$ & $14.91 \mathrm{a} \pm 0.17$ & $6.22 \mathrm{~b} \pm 0.20$ & $5.41 \mathrm{~b} \pm 0.18$ \\
\hline SFA & $571.45 \mathrm{a} \pm 14.87$ & $596.87 \mathrm{~b} \pm 1.01$ & $356.37 c \pm 0.41$ \\
\hline MUFA & $276.46 \mathrm{a} \pm 5.23$ & $285.38 \mathrm{a} \pm 2.24$ & $167.82 \mathrm{~b} \pm 0.68$ \\
\hline PUFA & $36.92 \mathrm{a} \pm 0.20$ & $26.36 \mathrm{a} \pm 0.42$ & $20.50 \mathrm{~b} \pm 0.27$ \\
\hline$n-6$ & $32.21 \mathrm{a} \pm 0.26$ & $22.31 b \pm 0.39$ & $18.32 \mathrm{~b} \pm 0.28$ \\
\hline$n-3$ & $4.71 \mathrm{a} \pm 0.13$ & $4.05 a \pm 0.06$ & $2.16 b \pm 0.03$ \\
\hline PUFA/SFA & $0.06 \mathrm{a} \pm 0.02$ & $0.04 \mathrm{a} \pm 0.03$ & $0.06 a \pm 0.02$ \\
\hline$n-6 / n-3$ & $6.85 \mathrm{a} \pm 0.23$ & $5.52 \mathrm{a} \pm 0.09$ & $8.49 b \pm 0.15$ \\
\hline
\end{tabular}

* mean \pm standard deviation of the results of triplicate analysis of five different lots $(n=15)$. SFA = saturated fatty acids, MUFA = monounsaturated fatty acids, PUFA = polyunsaturated fatty acids, n- $6=$ omega- 6 fatty acids, n-3 = omega- 3 fatty acids and CLA (conjugated linoleic acid). Means followed by different letters in the same line are significantly different by Tukey's test at $5 \%$ probability level 


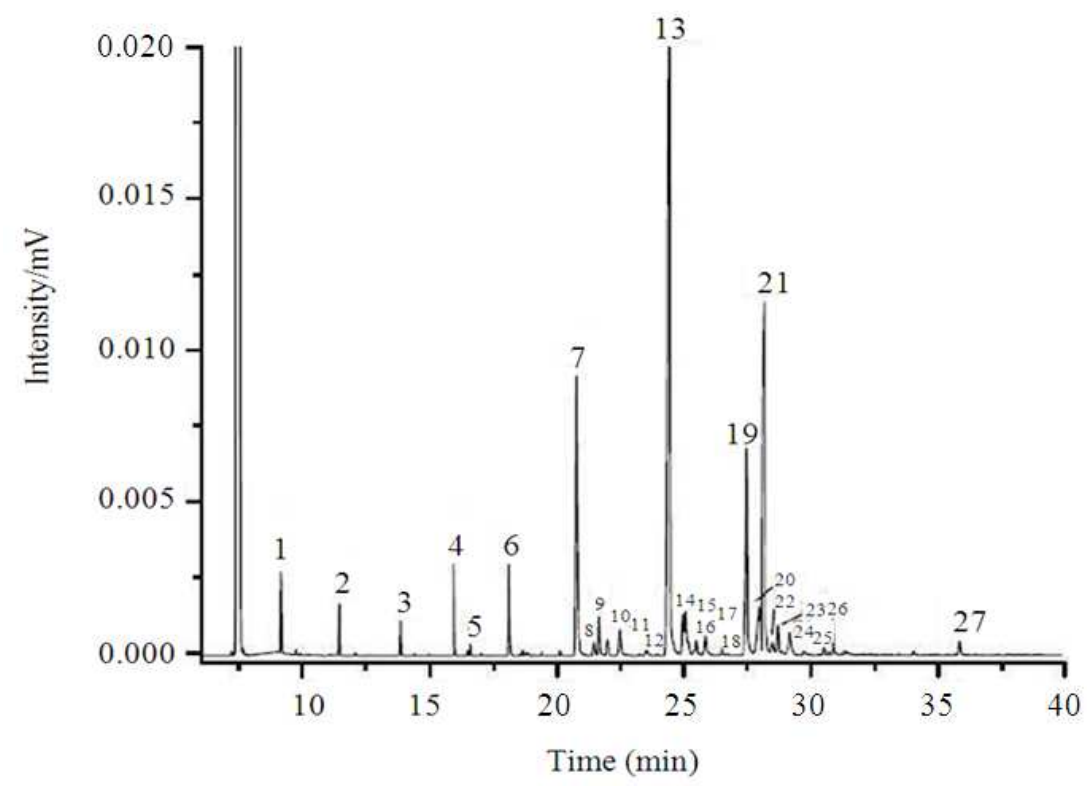

Fig. 1: Representative chromatogram of the analyzed milk and yoghurt samples (1) 4:0. (2) 6:0.(3) 8:0. (4) 10:0. (5) 11:0. (6) 12:0. (7) 14:0. (8) 14:1n-11. (9) 14:1n-9. (10) 14:1n-7. (11) 15:0. (12) 15:1n-7. (13) 16:0. (14) 16:1n-1. (15) 16:1n-9. (16) 16:1n-7. (17) 17:0. (18) 17:1n-7. (19) 18:0. (20) 18:1t. (21) 18:1n-9. (22) 18:1n7. (23) 18:2n-6t. (24) 18:2n-6. (25) 18:3n-3. (26) 18:2c9t11. (27) 23:0 (internal standard)

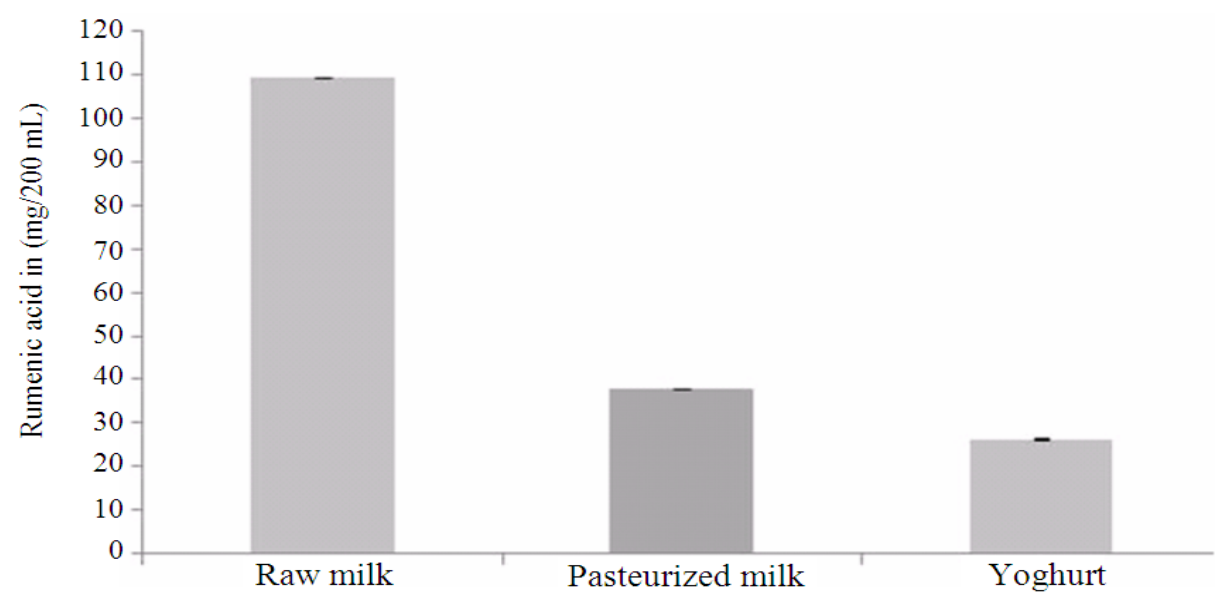

Fig. 2: CLA content in $(\mathrm{mg} / 200 \mathrm{~mL})$ of raw milk, pasteurized milk and yoghurt

\section{DISCUSSION}

As can be observed in Table 1, there were significant differences in total lipid content between raw milk, pasteurized milk and yoghurt. The results of both milk types were within the requirements of minimum fat content of 3\% (BRASIL, 2002).

The fat contents are in agreement with the literature data for milk and yoghurt produced in ummer (Simionato et al., 2010). However, these values may vary largely with breed, lactation stage and animal age and diet (Chilliard et al., 2007; Simionato et al., 2010; Collomb et al., 2002; 2004).

The difference in total lipids after pasteurization resulted from standardization by high rotation equipment in order to remove eventual dirtiness. Then milk stored in the vertical tank after agitation was stored at low temperature $\left(5^{\circ} \mathrm{C}\right)$ and a thin fat layer with possible dirtiness was formed on the surface which was kept on the equipment. Thus its removal would reduce the lipid content. 
The difference in lipid content of yoghurt is due to the addition of stabilizers to increase product viscosity, which may reduce the quantity of milk in the formulation and the total lipids in the final product when compared to raw and pasteurized milk. The lipid content of yoghurt may vary with the yoghurt type (skimmed, partially skimmed and whole).

The main fatty acid were myristic (14:0), palmitic (16:0), stearic (18:0) and oleic (18:1n-9). As shown in Table $2,65 \%$ of the fatty acid was saturated, 32\% were monounsaturated and 3\% were polyunsaturated, those results are similar to those published by Ordonez (2005).

Many researchers have studied how the thermal processes used in the preservation of milk and its derivatives affect their nutritional and organoleptic properties (Pereda et al., 2008; Raynal-Ljutovac et al., 2007; Rynne et al., 2004).

These changes affect mainly the structure of proteins. However, we have not found any similar report on how pasteurization affects the fatty acid composition and content. Table 2 shows the quantity of each fatty acid quantified in both raw and pasteurized milk samples and also in yoghurt samples. The total FAs (sum SFAs + MUFAs + PUFAs) are $544.69 \mathrm{mg}$ $\mathrm{g}^{-1}, 884.83 \mathrm{mg} \mathrm{g}^{-1}$ and $908.61 \mathrm{mg} \mathrm{g}^{-1}$ for yoghurt, raw milk and pasteurized milk, respectively. Both the latest results seem correct, the remaining $100 \mathrm{mg}$ being probably glycerol and unsaponifiable. However the value for yoghurt lipids looks questionable. One hypotheses is that there are a lot of Free Fatty Acid (FFAs) in yoghurt due to microbiological starter culture activity during process. Several studies have reported that the addition of lactic acid bacteria to dairy products may contribute to the production of FFAs by lipolysis of milk fat (Coskun and Ondul, 2004; Kurmann, 1988). FFAs are not methylated in the analytical conditions applied in this study, so they are not taking into account in the results. The total FFAs in terms of acid degree values significantly increased during fermentation and storage of yoghurts (Yadav et al., 2007). SFA, MUFA and PUFA contents decrease in yoghurt, but, the percentage de SFA in relation of total lipids is equal $65 \%$ in all raw milk and pasteurized milk samples.

The Polyunsaturated Fatty Acid (PUFA) (Table 2) decreased, as expected, by $28.6 \%$ after pasteurization, from $36.92 \pm 0.20$ to $26.36 \pm 0.42 \mathrm{mg} \mathrm{g}^{-1}$ demonstrating that heating degrades its structure. Probably the acidic $\mathrm{pH}$ of milk and heating favor the attack of the double bonds by oxygen, forming volatile compounds such as alcohols and ketones, thus decreasing the amount of PUFA. The decrease in PUFA from pasteurized milk to yoghurt is smaller $(22.23 \%)$ due to the addition of starch and gelatin as stabilizers, which form a network when heated that retains the fat, moisture and protein and prevents syneresis on the shelf.

The PUFA that has the greatest variation was rumenic acid, ranging from $14.91 \pm 10.17 \mathrm{mg} \mathrm{g}^{-1}$ in raw milk to $6.22 \pm 0.20 \mathrm{mgg}^{-1}$ in pasteurized milk, a reduction of $58.28 \%$. Loor and Herbein (2003) found that concentration of $\mathrm{c} 9, \mathrm{t} 11-18: 2$ was greater in response to soybean oil or soybean oil plus conjugated linoleic acids $\left(7 \mathrm{mg} \mathrm{g}^{-1}\right)$ compared with canola oil or canola oil plus conjugated linoleic acids $\left(5 \mathrm{mg} \mathrm{g}^{-1}\right)$ and accounted for the effect of oil on its yield in milk fat. The concentration of $c 9, \mathrm{t} 11-18: 2$ in milk fat tended ( $p$ $=0.08$ ) to be lower when cows were fed soybean oil plus conjugated linoleic acids.

Processing yoghurt from pasteurized milk showed a $13.14 \%$ reduction in the CLA content which was smaller than the \% CLA reduction from raw to pasteurized milk, due milk heating in the production of yoghurt $\left(85^{\circ} \mathrm{C} / 10 \mathrm{~min}\right)$ and the elimination of a large part of the dissolved oxygen Ordonez (2005). Thus, the formation of volatile compounds caused by the attack of double bonds by oxygen is smaller and so is the reduction of the fatty acid content in yoghurt.

The n-6/n-3 ratios of raw milk, pasteurized milk and yoghurt samples were $6.85 \pm 0.23,5.52 \pm 0.09$ and $8.49 \pm 0.15$, respectively. All values were within the recommendations of United Nations agency for food and agriculture (FAO, 2007) which suggests a ratio between 5 and 10. The decrease of this ratio in pasteurized milk is due to the reduction in CLA, thus, of $n-6$. Its increase in yoghurt is due to the reduction in n-3.

Recent research shows that CLA and its precursor, vaccenic acid (a naturally occurring trans fatty acid), in milk fat may protect against development and progression of atherosclerosis (Kurmann, 1988). Studies performed in countries such as Germany indicate that to provide anticarcinogenic effects, women must ingest $360 \mathrm{mg}$ of CLA per day and men, $440 \mathrm{mg}$, $2 / 3$ being from milk and dairy products and $1 / 4$ from meat and derivatives (Sieber et al., 2004). Figure 2 gives the amounts of CLA in $\mathrm{mg} / 200 \mathrm{~mL}$ of food for raw milk, pasteurized milk and yoghurt.

Safety concerns regarding the use of CLA in humans are not conclusive and need further investigation (Park and Pariza, 2007).

\section{CONCLUSION}

Pasteurization drastically reduces the CLA content in milk, showing that animal diet supplementation to increase CLA in milk is not advantageous, as pasteurization is a requirement for milk conservation. 
As to the consumption of milk and its derivatives, the intake of yoghurt is recommended since it has a lower content of saturated fatty acid to compared pasteurized milk, is rich in calcium, has easily digestible proteins due to denaturation by heating, has less lactose than milk, which is mostly digested by microorganisms during fermentation, thus being acceptable by those with allergy to lactose and has a large CLA content.

\section{REFERENCES}

Bannon, C.D., J.D. Craske, N.T. Hai, N.L. Harper and K.L. O'Rourke, 1982. Analysis of fatty acid methyl esters with high accuracy and reliability : II. Methylation of fats and oils with boron trifluoridemethanol. J. Chrom. A, 247: 63-69. DOI: 10.1016/S0021-9673(00)84856-6

Belury, M.A., K.P. Nickel, C.E. Bird and Y. Wu, 1996. Dietary conjugated linoleic acid modulation of phorbol ester skin tumor promotion. Nutr. Cancer, 26: 149-157. PMID: 8875552

BRASIL, 2002. Ministério da Agricultura, do Abastecimento. Departamento de Inspeção de Produtos de Origem Animal.

Chardigny, J.M., F. Destaillats, C. Malpuech-Brugère, J. Moulin and D.E. Bauman et al., 2008. Do trans fatty acids from industrially produced sources and from natural sources have the same effect on cardiovascular disease risk factors in healthy subjects? Results of the trans Fatty Acids Collaboration (TRANSFACT) study. Am. J. Clin. Nutr., 87: 558-566.

Chardigny, J.M., O. Hasselwander, M. Genty, K. Kraemer and A. Ptock et al., 2003. Effect of conjugated FA on feed intake, body composition and liver FA in mice. Lipids, 38: 895-902. PMID: 14584596

Chilliard, Y., F. Glasser, A. Ferlay, L. Bernard and J. Rouel et al., 2007. Diet, rumen biohydrogenation and nutritional quality of cow and goat milk fat. Eur. J. Lipid Sci. Technol., 8: 828-855. DOI: 10.1002/ejlt.200700080

Collomb, M., U. Bütikofer, R. Sieber, B. Jeangros and J.O. Bosset, 2002. Correlation between fatty acids in cows' milk fat produced in the Lowlands, Mountains and Highlands of Switzerland and botanical composition of the fodder. Int. Dairy J., 12: 661-666. DOI: 10.1016/S0958-6946(02)00062-6

Collomb, M., H. Sollberger, U. Bütikofer, R. Sieber and W. Stoll et al., 2004. Impact of a basal diet of hay and fodder beet supplemented with rapeseed, linseed and sunflowerseed on the fatty acid composition of milk fat. Int. Dairy J., 14: 549-559. DOI: 10.1016/j.idairyj.2003.11.004
Cook, M.E., C.C. Miller, Y. Park and M. Pariza, 1993. Immune modulation by altered nutrient metabolism: Nutritional control of immuneinduced growth depression. Poul. Sci., 72: 13011305. PMID: 8346156

Coskun, H. and E. Ondul, 2004. Free fatty acid accumulation by mesophilic lactic acid bacteria in cold-stored milk. J. Microbiol., 42: 133-138. PMID: 15357307

Degrace, P., L. Demizieux, J. Gresti, J.M. Chardigny and J.L. Sebedio et al., 2003. Association of liver steatosis with lipid oversecretion and hypotriglyceridaemia in C57BL/6j mice fed trans10,cis-12-linoleic acid. FEBS Lett., 546: 335-339. PMID: 12832064

Autores, V., 2009. Trans Fatty Acids in Human Nutrition. 2nd Edn., Woodhead Publishing Limited, Bridgwater, ISBN-10: 0955251230, pp: 448.

Dugan, M.E.R., J.L. Aalhus, A.L. Schaefer and J.K.G. Kramer, 1997. The effect of conjugated linoleic acid on fat to lean repartitioning and feed conversion in pigs. Can. J. Anim. Sci., 77: 723725. DOI: 10.4141/A97-084

FAO, 2007. Food and Agriculture Organization of the United Nations. Food and Agriculture Organization.

Folch, J., M. Lees and G.H.S. Stanley, 1957. A simple method for the isolation and purification of total lipides from animal tissues. J. Biol. Chem., 226: 497-509. PMID: 13428781

Gaullier, J.M., J. Halse, K. Hoye, K. Kristiansen and H. Fagertun et al., 2005. Supplementation with conjugated linoleic acid for 24 months is well tolerated by and reduces body fat mass in healthy, overweight humans. J. Nutr., 135: 778-784.

Gnädig, S., J.F. Chamba, E. Perreard, S. Chappaz and J.M. Chardigny et al., 2004. Influence of manufacturing conditions on the conjugated linoleic acid content and the isomer composition in ripened French Emmental cheese. J. Dairy Res., 71: 367-371. PMID: 15354584

Hubbard, N.E., D. Lim, L. Summers and K.L. Erickson, 2000. Reduction of murine mammary tumor metastasis by conjugated linoleic acid. Cancer Lett., 150: 93-100. PMID: 10755392

Ip, C., Y. Dong, M.M. Ip, S. Banni and G. Carta et al., 2002. Conjugated linoleic acid isomers and mammary cancer prevention. Nutr. Cancer, 43: 5258. PMID: 12467135

Jiang, J., L. Björck and R. Fondén, 1998. Production of conjugated linoleic acid by dairy starter cultures. J. Applied Microbiol., 85: 95-102. PMID: 9721660 
Joseph, J.D. and R.G. Ackman, 1982. Capillary column gas chromatographic method for analysis of encapsulated fish oils and fish oil ethyl esters: Collaborative study. J. AOAC Int., 75: 488-506.

Kurmann, J.A., 1988. Starters of fermented milks: Starters with selected intestinal bacteria. Int. Dairy Fed. Bull., 227: 41-55.

Kepler, C.R., K.P. Hirons, J.J. McNeill and S.B. Tove, 1966. Intermediates and products of the biohydrogenation of linoleic acid by Butyrivibrio fibrisolvens. J. Biol. Chem., 241: 1350-1354.

Kramer, J.P.G., P.W. Parodi, R.G. Jensen, M.M. Mossoba and M.P. Yurawecz et al., 1998. Rumenic acid: a proposed common name for the major conjugated linoleic acid isomer found in natural products. Lipids, 33: 835-835. PMID: 9727617

Lavillonnière, F., V. Chajes, J.C. Martin, J.L. Sébédio and C. Lhuyllery et al., 2003. Dietary purified cis9, trans-11 conjugated linoleic acid isomer has anticarcinogenic properties in chemically induced mammary tumors in rats. Nutr. Cancer, 45: 190194. PMID: 12881013

Ledoux, M. and L. Laloux, 2006. Rumenic acid contents evolution from milk to butter: seasonal and regional variations. Sci. Alim., 26: 123-141.

Ledoux, M., L. Laloux, J.J. Fontaine, Y.A. Carpentier and J.M. Chardigny et al., 2007. Rumenic acid significantly reduces plasma levels of LDL and small dense LDL cholesterol in hamsters fed a cholesterol- and lipid-enriched semi-purified diet. Lipids, 42: 135-141. PMID: 17393219

Loor, J.J. and J.H. Herbein, 2003. Dietary canola or soybean oil with two levels of Conjugated Linoleic Acids (CLA) alter profiles of 18:1 and 18:2 isomers in blood plasma and milk fat from dairy cows. Anim. Feed Sci., 103: 63-83.

Molkentin, J., 1999. Bioactive lipids naturally occurring in bovine milk. Nahrung, 43: 185-189. PMID: 10399352

Mourão, D.M., J.B.R. Monteiro, N.M.B. Costa, P.C. Stringheta and V.P.R. Minin et al., 2005. Ácido linoléico conjugado e perda de peso. Braz. J. Nutr., 18 391-399. DOI: 10.1590/S141552732005000300011

Ordonez, J.L., 2005. Tecnologia de Alimentos-Origem Animal. 1st Edn., Artmed, Porto Alegre, ISBN-10: 8536304367, pp: 280.

Ou, L., C. Ip, B. Lisafeld and M.M. Ip, 2007. Conjugated linoleic acid induces apoptosis of murine mammary tumor cells via Bcl-2 loss. Biochem. Bioph. Res. Co., 356: 1044-1049. PMID: 17400188
Park, Y. and M.W. Pariza, 2007. Mechanisms of body fat modulation by Conjugated Linoleic Acid (CLA). Food Res. Inter., 40: 311-323. DOI: 10.1016/j.foodres.2006.11.002

Pereda, J.., D.P. Jaramillo, J.M. Quevedo, V. Ferragut and B. Guamis et al., 2008. Characterization of volatile compounds in ultra-high-pressure homogenized milk. Inter. Dairy J., 18: 826-834. DOI: 10.1016/j.idairyj.2007.12.002

Raynal-Ljutovac, K., Y.W. Park, F. Gaucheron and S. Bouhallab, 2007. Heat stability and enzymatic modifications of goat and sheep milk. Small Rumin. Res., 68: 207-220. DOI: 10.1016/j.smallrumres.2006.09.006

Rynne, N.M., T.P. Beresford, A.L. Kelly and T.P. Guinee, 2004. Effect of milk pasteurization temperature and in situ whey protein denaturation on the composition, texture and heat-induced functionality of half-fat Cheddar cheese. Inter. Dairy J., 14: 989-1001. DOI: 10.1016/j.idairyj.2004.03.010

Shantha, N.C., L.N. Ram, J. O'leary, C.L. Hicks and E.A. Decker, 1995. Conjugated linoleic acid concentrations in dairy products as affected by processing and storage. J. Food Sci., 60: 695-697. DOI: 10.1111/j.1365-2621.1995.tb06208.x

Sieber, R., M. Collomb, A. Aeschlimann, P. Jelen and H. Eyer, 2004. Impact of microbial cultures on conjugated linoleic acid in dairy products - a review. Int. Dairy J., 14: 1-15.

Simionato, J.I., J.C. Garcia, G.T. Santos, C.C. Oliveira and J.V. Visentainer et al., 2010. Validation of the determination of fatty acids in milk by gas chromatography. J. Braz. Chem. Soc., 21: 520-524.

StatSoft, 2005. Statistica 7.0 Software, StatSoft. Statistica for Windows, (computer program manual). Stat soft Inc.

Yadav, H., S. Jain and P.R. Sinha, 2007. Production of free fatty acids and conjugated linoleic acid in probiotic dahi containing Lactobacillus acidophilus and Lactobacillus casei during fermentation and storage. Inter. Dairy J., 17: 1006-1010. DOI: 10.1016/j.idairyj.2006.12.003 